\title{
EVIDENCE INDICATING PARTICIPATION OF THE SEROTONERGIC SYSTEM IN CONTROLLING FEEDING BEHAVIOR IN Coturnix japonica (GALLIFORMES: AVES)
}

\author{
REIS, L. C., ${ }^{1}$ ALMEIDA, A. C., ${ }^{2}$ CEDRAZ-MERCEZ, P. L., ${ }^{3}$ OLIVARES, E. L., ${ }^{1}$ \\ MARINHO JR., A. ${ }^{1}$ and THOMAZ, C. M. ${ }^{4}$ \\ ${ }^{1}$ Departamento de Ciências Fisiológicas, Instituto de Biologia, UFRuralRJ \\ ${ }^{2}$ Bolsista de Iniciação Científica do CNPq \\ ${ }^{3}$ Bolsista de Iniciação Científica da FAPERJ \\ ${ }^{4}$ Monografista do Curso de Ciências Biológicas, UFRuralRJ \\ Correspondence to: Luís Carlos Reis, DCF/IB/UFRuralRJ, Rod. BR 465, km 7, CEP 23890-000, \\ Seropédica, RJ, Brazil, e-mail: lcreis@ufrrj.br \\ Received July 14, 2003 - Accepted September 22, 2003 - Distributed May 31, 2005
}

(With 5 figures)

\begin{abstract}
We investigated participation of the brain serotonergic system in food intake control by using oral and systemic administration of serotonin precursors in quails (Coturnix japonica). Dietary supplemental tryptophan $(0.1-50.0 \mathrm{~g} / \mathrm{kg})$ provoked a dose-dependent inhibition of food intake during a $5-\mathrm{h}$ observation period, which persisted up to $24 \mathrm{~h}$ for doses of 30.0 and $50.0 \mathrm{~g} / \mathrm{kg}$. Normally fed and fasted animals treated with hydroxytryptophan $(12.5-50.0 \mathrm{mg} / \mathrm{kg}$ ) by the intracoelomic route showed an acute inhibition of food intake. Hypophagia in fasted birds was only effective when the precursor was administered immediately before food presentation. A similar response was obtained by administering serotonin $(0.125-2.5 \mathrm{mg} / \mathrm{kg}, s c)$, with animals showing a hypnogenic response within the first ten minutes after administration, suggesting that, in contrast to mammals, the amine crosses the bloodbrain barrier in quails. Administration of hydroxytryptophan at all doses tested induced significant dipsogenic behavior despite the concomitant hypnogenic response. The results suggest the involvement of serotonergic pathways in food intake control in quails and also show, for the first time, hypnogenic action induced by serotonin and a hyperdipsic effect elicited by hydroxytryptophan.
\end{abstract}

Key words: feeding behavior, serotonergic system, tryptophan, hydroxytryptophan, serotonin, Coturnix japonica.

\section{RESUMO}

\section{Evidência da participação do sistema serotonérgico no controle do comportamento alimentar em Coturnix japonica (Galliformes: Aves)}

Investigamos a participação do sistema serotonérgico cerebral no controle da ingestão de alimento em codornas (Coturnix japonica) por meio da administração oral e sistêmica de precursores da serotonina. A suplementação dietética com triptofano $(0,1-50,0 \mathrm{~g} / \mathrm{kg}$ de ração) provocou inibição dose-dependente da ingestão de alimento em $5 \mathrm{~h}$ de avaliação, que se manteve ao final de $24 \mathrm{~h}$ com doses de 30,0 e $50,0 \mathrm{~g} / \mathrm{kg}$. Codornas tratadas com hidroxitriptofano $(12,5-50,0 \mathrm{mg} / \mathrm{kg}$, via intracoelomática) exibiram aguda inibição da ingestão alimentar, tanto as normoalimentadas quanto as submetidas ao jejum. Nas aves em jejum, a resposta hipofágica foi efetiva apenas quando a administração do precursor foi feita imediatamente antes da oferta de alimento. Resposta similar foi alcançada com a administração de serotonina $(0,125-2,5 \mathrm{mg} / \mathrm{kg}, \mathrm{sc})$. Nos minutos iniciais após a administração desenvolveu-se resposta hipnogênica, implicando assunção de que essa amina atravessa a barreira hemato-encefálica em codornas, 
diferentemente do observado em mamíferos. A administração de hidroxitriptofano em todas as doses utilizadas induziu intensa resposta dipsogênica, não obstante o desenvolvimento concomitante de resposta hipnogênica. Os resultados sugerem o envolvimento de vias serotonérgicas no controle da ingestão de alimento em codornas e mostram pela primeira vez as ações hipnógena, induzida pela serotonina e hiperdipsética, pelo hidroxitriptofano.

Palavras-chave: comportamento alimentar, sistema serotonérgico, triptofano, hidroxitriptofano, serotonina, Coturnix japonica.

\section{INTRODUCTION}

The participation of the brain serotonergic system in the regulation of satiety and appetite in mammals has been widely accepted in the literature, with most reports referring to studies conducted on rodents (Blundell, 1984, 1991; Curzon, 1990). Neurons of the brain serotonergic system are distributed along the raphe and in the brain stem, with one mesencephalic group in particular projecting towards diencephalic structures related to appetite modulation and the expression of satiety (Blundell, 1984, 1991; Curzon, 1990). Anorexic and satiety responses involve 5-HT2C receptors and possibly 5-HT1B sites found in hypothalamic loci responsible for primary integration of feeding behavior (Blundell, 1984, 1991; Curzon, 1990).

The topographic and functional organization of the serotonergic system has been highly conserved from reptiles to birds and mammals (Dubé \& Parent, 1981; Parent, 1981; Parent et al., 1981; Duchala et al., 1984; Sako et al., 1986; Cozzi et al., 1991; Challet et al., 1996). In fact, the ubiquitous phylogenetic distribution of the serotonergic system has raised the hypothesis that this system represents a neural substrate integrating similar mechanisms that remain intact throughout the vertebrate kingdom (Parent, 1981). According to this hypothesis, a single serotonergic neuron of the mesencephalic raphe projects axonal fibers to distant rostral areas where it exerts a polymodal control on prosencephalic loci involved in the homeostasis of autonomic, neuroendocrine, metabolic, and behavioral functions in vertebrates (Azmitia \& Segal, 1978; Parent, 1981; Azmitia, 1987). Serotonin (5-hydroxytryptamine), a neurotransmitter released at serotonergic synapses, is synthesized from the amino acid L-tryptophan. Initially, the amino acid is hydroxylated by L-5tryptophan hydroxylase (TPO) to L-5hydroxytryptophan, which is subsequently decarboxylated by L-aromatic amino acid decarboxylase (L-AAD) to serotonin (Tyce, 1990).
In birds, a dense serotonergic-fiber distribution has been identified in diencephalic regions known to be involved in controlling feeding behavior (Parent, 1981; Duchala et al., 1984; Sako et al., 1986; Challet et al., 1996). However, studies regarding the role of serotonergic pathways in the control of food intake in birds are rare (Rosebrough, 1996; Thomaz et al., 1998).

The role of the serotonergic system in regulating feeding behavior has been analyzed through the use of initial and immediate synthesis precursors, releasers, agonists, and presynaptic reuptake inhibitors of serotonin (Fernstrom \& Wurtman, 1971a, b; Blundell, 1984; Blundell \& Hill, 1987; Curzon, 1990, 1991).

In the present study, we provide evidence indicating involvement of the serotonergic system in regulating feeding behavior in quails (Coturnix japonica). To this end, we used classical experimental procedures, e.g., dietary supplementation with L-tryptophan and intracoelomic injection of L-5-hydroxytryptophan, which are the initial and immediate precursors of neuronal serotonin synthesis, respectively (Tyce, 1990).

\section{MATERIAL AND METHODS}

\section{Animals and housing conditions}

Male quails weighing 130 to $160 \mathrm{~g}$ were housed in special cages equipped with individual volumetric drinking bottles and food containers, under a 12/ $12 \mathrm{~h}$ light/dark cycle at 25 to $30^{\circ} \mathrm{C}$ ambient temperature, with water and ration (Purina for quails, $16 \%$ crude protein) available ad libitum throughout the period of adaptation to laboratory conditions.

\section{Experimental groups and procedures}

The present study was divided into the following five experimental series:

I Normally fed quails $(\mathrm{N}=12)$ treated with L-tryptophan (L-TRP; Sigma) added to the 
ration at doses of $0,0.1,1.0,10.0,20.0$, 30.0 , and $50.0 \mathrm{mg} / \mathrm{kg}$ ration. Food intake was measured immediately, and after 60 , 120, 180, 240, $300 \mathrm{~min}$, and $24 \mathrm{~h}$.

II Normally fed quails $(\mathrm{N}=12)$ receiving L5-hydroxytryptophan (L-HTP; Sigma) intracoelomically (ic) at doses of $0,12.5$, 25.0 , and $50.0 \mathrm{mg} / \mathrm{kg}$. The animals were then deprived of food for $60 \mathrm{~min}$, and after this period ration was reintroduced together with water

III Animals $(\mathrm{N}=12)$ submitted to a $6 \mathrm{~h}$ fast and treated with L-HTP at doses of $0,12.5$, 25.0 , and $50.0 \mathrm{mg} / \mathrm{kg}$, ic, $60 \mathrm{~min}$ before food and water reintroduction.

IV Animals $(\mathrm{N}=12)$ submitted to a $6 \mathrm{~h}$ fast and treated with L-HTP at doses of 0, 12.5, 25.0 , and $50.0 \mathrm{mg} / \mathrm{kg}, i c, 1 \mathrm{~min}$ before food and water reintroduction.

$\mathrm{V}$ Animals ( $\mathrm{N}=12$ ) submitted to a $6 \mathrm{~h}$ fast and treated with serotonin (Sigma) at doses of $0.125,1.25$, and $2.5 \mathrm{mg} / \mathrm{kg}, s c, 1 \mathrm{~min}$ before food and water reintroduction.

A control group was included in each experimental series. In series I, control animals only received normal ration, while in series II, III, and IV the animals received $1.0 \mathrm{ml} / \mathrm{kg}$ vehicle $(0.15 \mathrm{M}$ saline, $i c)$. Intracoelomic and subcutaneous injections were applied with a $1 \mathrm{ml}$ syringe, attached to a $1 \mathrm{~cm}$ long needle having a 25-gauge diameter. Injections into the coelomic cavity were made at a $45^{\circ}$ angle in the medium quadrant of the pelvic wall. Protocols with normally fed quails were always filled at 1:00 p.m., following a 4-hour-fast beginning at 7:00 a.m. Food was re-offered immediately after fasting ended. Food intake was measured by using individual metal containers especially constructed for quail (13.4 $\mathrm{x}$ $2.8 \times 3.2 \mathrm{~cm}$ ) and equipped with a system to prevent food wastage. The weight of ingested ration was determined with an electronic precision scale. Cage cells were separated from one another by cardboard to prevent visual and physical contact between animals. Water intake in series II, III, and IV was determined with individual $60 \mathrm{ml}$ volumetric bottles.

\section{Statistical analysis}

Results are reported as means \pm standard error of the mean. Data were analyzed statistically by twotailed ANOVA and the paired or unpaired Student $t$ test when appropriate. Differences between means were considered to be significant when $\mathrm{p} \leq 0.05$.

\section{RESULTS}

Dietary supplementation with L-TRP inhibited food intake in quails in a dose-dependent manner. At $300 \mathrm{~min}$, food intake decreased from $9.34 \pm 0.41$ $\mathrm{g}$ (control) to $9.12 \pm 0.38,8.85 \pm 0.39,7.67 \pm 1.04$, $7.09 \pm 0.6,5.05 \pm 0.77$, and $4.29 \pm 0.33 \mathrm{~g}$ in animals treated with $0.1,1.0,10.0,20.0,30.0$, and $50.0 \mathrm{~g} / \mathrm{kg}$ L-TRP, respectively. At 30.0 and 50.0 $\mathrm{g} / \mathrm{kg}$, the hypophagic response persisted for $24 \mathrm{~h}$ (control: $20.1 \pm 1.3 ; 30.0 \mathrm{~g} / \mathrm{kg}$ : $11.47 \pm 1.56,50.0 \mathrm{~g}$ / $\mathrm{kg}: 10.01 \pm 0.85 \mathrm{~g}$ ingested food) (Fig. 1).

Administration of L-HTP (60 min before food presentation) to normally fed quails also inhibited food intake in a dose-dependent manner (Fig. 2). After $60 \mathrm{~min}$, food intake was $2.76 \pm 0.28$ vs $1.91 \pm 0.33$ $\mathrm{g}, 3.2 \pm 0.31$ vs $1.76 \pm 0.33 \mathrm{~g}$, and $3.1 \pm 0.27 v s$ $1.32 \pm 0.36 \mathrm{~g}$ for the control group compared to the groups receiving 12.5 (Fig. 2A), 25.0 (Fig. 2B), and 50.0 (Fig. 2C) mg/kg L-HTP, respectively ( $\mathrm{p}<0.05$ for all comparisons). At $300 \mathrm{~min}$, food intake was still significant after administration of the $50.0 \mathrm{mg} /$ $\mathrm{kg}$ dose $(16.19 \pm 2.71$ vs $12.77 \pm 1.33 \mathrm{~g}, \mathrm{p}<0.05)$.

Injection of previously fasted quails with LHTP at doses of 12.5, 25.0, and $50.0 \mathrm{mg} / \mathrm{kg}$ (Figs. 2A, 2B, 2C) $60 \mathrm{~min}$ before food presentation did not alter the food intake response (Figs. 3A, 3B, 3C). In contrast, administration of L-HTP at the same doses $1 \mathrm{~min}$ before food presentation caused a significant reduction in food intake $(2.64 \pm 0.22$ vs $1.39 \pm 0.29 \mathrm{~g}, 2.54 \pm 0.34$ vs $0.88 \pm 0.31 \mathrm{~g}$ and $2.68 \pm 0.46$ vs $0.85 \pm 0.3 \mathrm{~g}$, at $60 \mathrm{~min} ; \mathrm{p}<0.05$ for all treatments) (Figs. 4A, 4B, 4C).

Serotonin administration at doses of 0.125 , 1.25 , and $2.5 \mathrm{mg} / \mathrm{kg}$ inhibited food and water intake (Figs. 5A and B). In addition, serotonin elicited a hypnogenic response, especially at doses of 1.25 and $2.5 \mathrm{mg} / \mathrm{kg}$, which persisted for more than $10 \mathrm{~min}$.

Administration of L-HTP at all doses and under all experimental conditions induced a hyperdipsic response (Figs. 2, 3, 4). In contrast, serotonin treatment reduced water intake (Fig. 5).

\section{DISCUSSION}

The hypophagic response observed in quails confirms observations made in mammals demonstrating that dietary tryptophan supplementation or oral or systemic tryptophan overload increases brain serotonin synthesis, with consequent inhibition of food intake (Fernstron \& Wurtman, 1971a, b; 1983; Blundell, 1984; Curzon, 1990, 1991). 


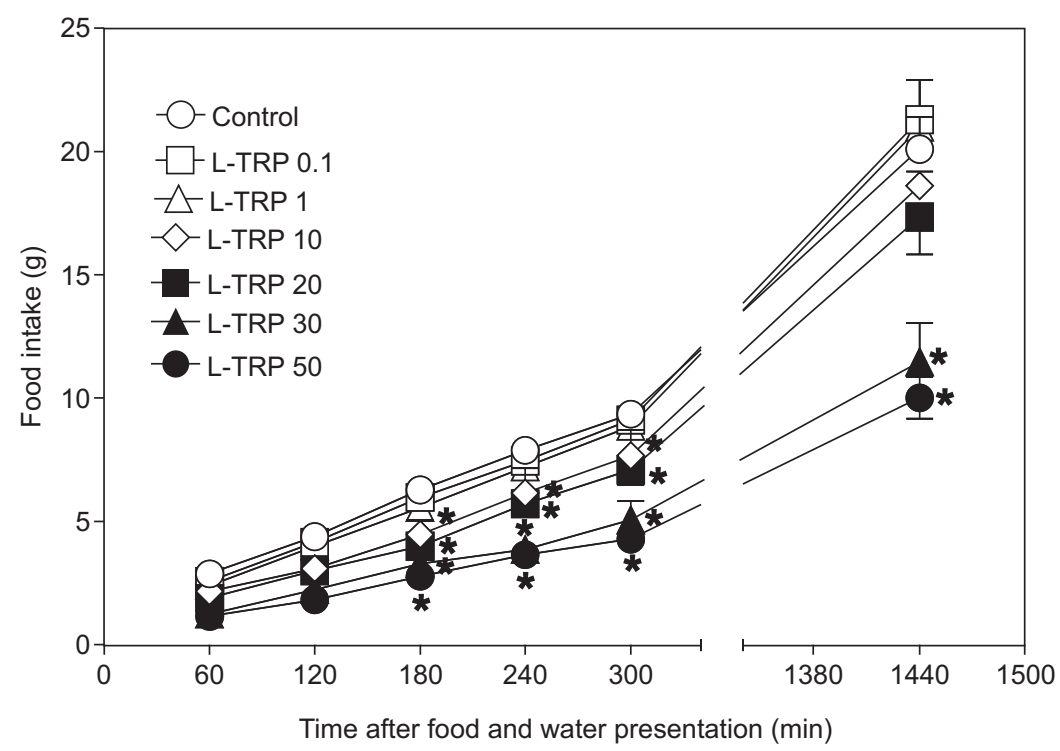

Fig. 1 - Effect of supplemental L-tryptophan (L-TRP; 0.1, 1.0, 10.0, 20.0, 30.0, and 50.0 g/kg ration) on food intake in quails (Coturnix japonica). Data are reported as means $\pm \mathrm{SE}$. $* \mathrm{p}<0.05$ compared to the control group.

The response pattern developed as a function of the L-TRP dose administered; however, concentrations equal to or lower than $10.0 \mathrm{mg} / \mathrm{kg}$ led to a reversal of hypophagia after $24 \mathrm{~h}$. This reversal probably depended on the development of plasticity in the systems that regulate food intake (e.g., reduction in the neuronal availability of L-TRP and subsequent decline in serotonin biosynthesis or adaptive responses of the counter-regulatory systems). It should be emphasized that the control of TPO activity in mammalian serotonergic neurons is limited by the substrate concentration and, therefore, higher L-TRP concentrations are required for enzymatic inhibition compared to the L-tyrosine levels necessary for tyrosine hydroxylase inhibition in catecholaminergic neurons (Tyce, 1990; Boadle-Biber, 1993). Since the $K_{\mathrm{m}}$ of L-TRP is high in serotonergic neurons, TPO saturation is only reached at supraphysiological concentrations of the substrate (Fernstrom \& Wurtman, 1971a, b, 1983; Tyce, 1990; Curzon, 1991; Boadle-Biber, 1993). No observations of this kind have been made for quails but the same phenomenon is likely to occur in birds. In chickens (Gallus domesticus), supplemental L-TRP at a maximum dose of $16.7 \mathrm{~g} / \mathrm{kg}$ has been reported to reduce food intake; this is associated with an increase in brain serotonin concentration during peak intake (Rosebrough, 1996). In the present study, the L-TRP concentrations required to obtain a hypophagic response in quails were proportionally much higher than those used in mammals (Fernstron, 1983; Curzon, 1990, 1991), and even higher than those reported by Rosebrough (1996) for chickens. However, we cannot yet confirm if this finding was due to a lower neuronal L-TRP uptake capacity or to a lower affinity of TPO for the substrate, or even to a lower activity of L-AAD, the enzyme responsible for L-HTP decarboxylation. Future studies are necessary to elucidate at which level, ranging from the neuronal uptake of L-TRP to serotonin biosynthesis, this greater substrate availability to inhibit food intake of the serotonergic system in quails resides.

Inhibition of food intake in normally fed quails as a function of L-HTP dose administered is an argument in favor of the serotonergic hypothesis. The doses necessary to elicit a hypophagic response were comparable to those reported for mammals (Blundell, 1984, 1991; Curzon, 1990, 1991), possibly indicating that the L-HTP decarboxylation step does not represent a major limiting factor in serotonin biosynthesis.

Equally effective in quails submitted to fasting was L-HTP, but only when administered $1 \mathrm{~min}$ before food presentation. When food was offered 60 min after administration of the precursor, peak serotonin production possibly had already ceased and the precursor had been completely metabolized (or was no longer available). 

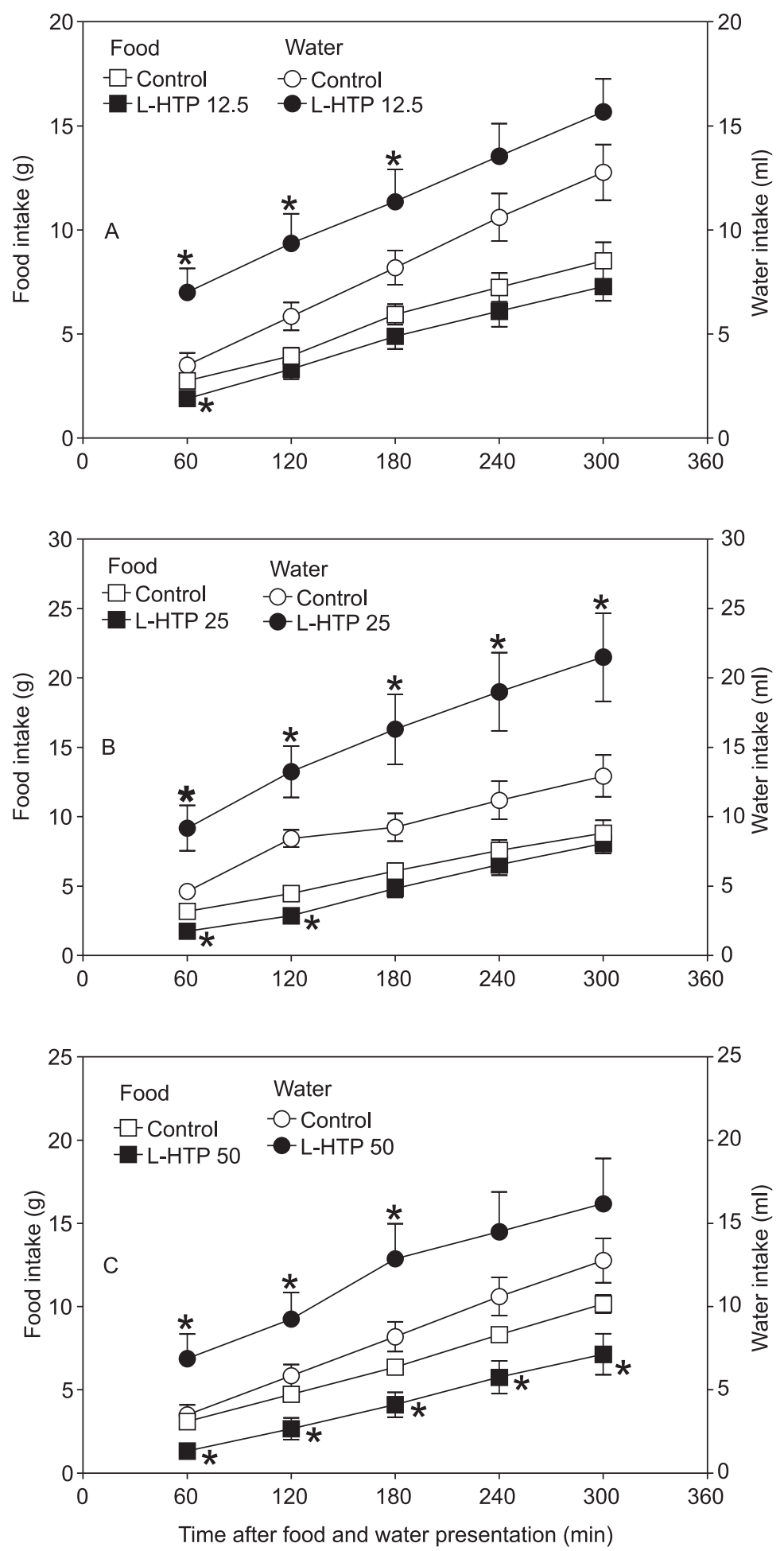

Fig. 2 - Effect of treatment with L-5-hydroxytryptophan (L-HTP), 12.5 (A), 25.0 (B), and 50.0 (C) $\mathrm{mg} / \mathrm{kg}, i c, 60 \mathrm{~min}$ before food and water presentation, on food and water intake in normally fed quails (Coturnix japonica). Data are reported as means $\pm \mathrm{SE}$. $* \mathrm{p}<$ 0.05 compared to the control group. 

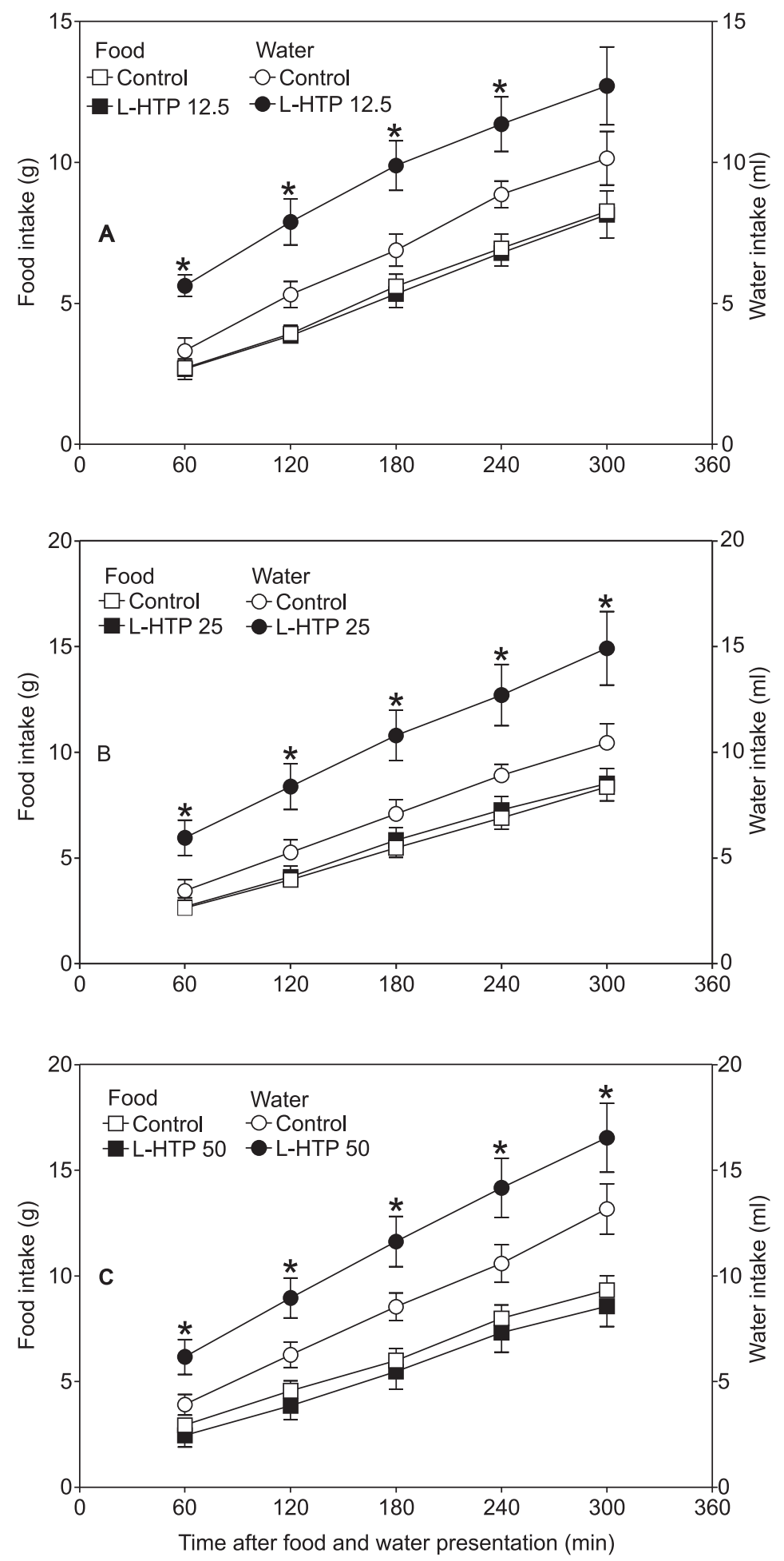

Fig. 3 - Effect of treatment with L-5-hydroxytryptophan (L-HTP), 12.5 (A), 25.0 (B), and 50.0 (C) $\mathrm{mg} / \mathrm{kg}, i c, 60 \mathrm{~min}$ before food and water presentation, on food and water intake in quails (Coturnix japonica) submitted to a $6 \mathrm{~h}$ fast. Data are reported as means \pm SE. * $p<0.05$ compared to the control group. 

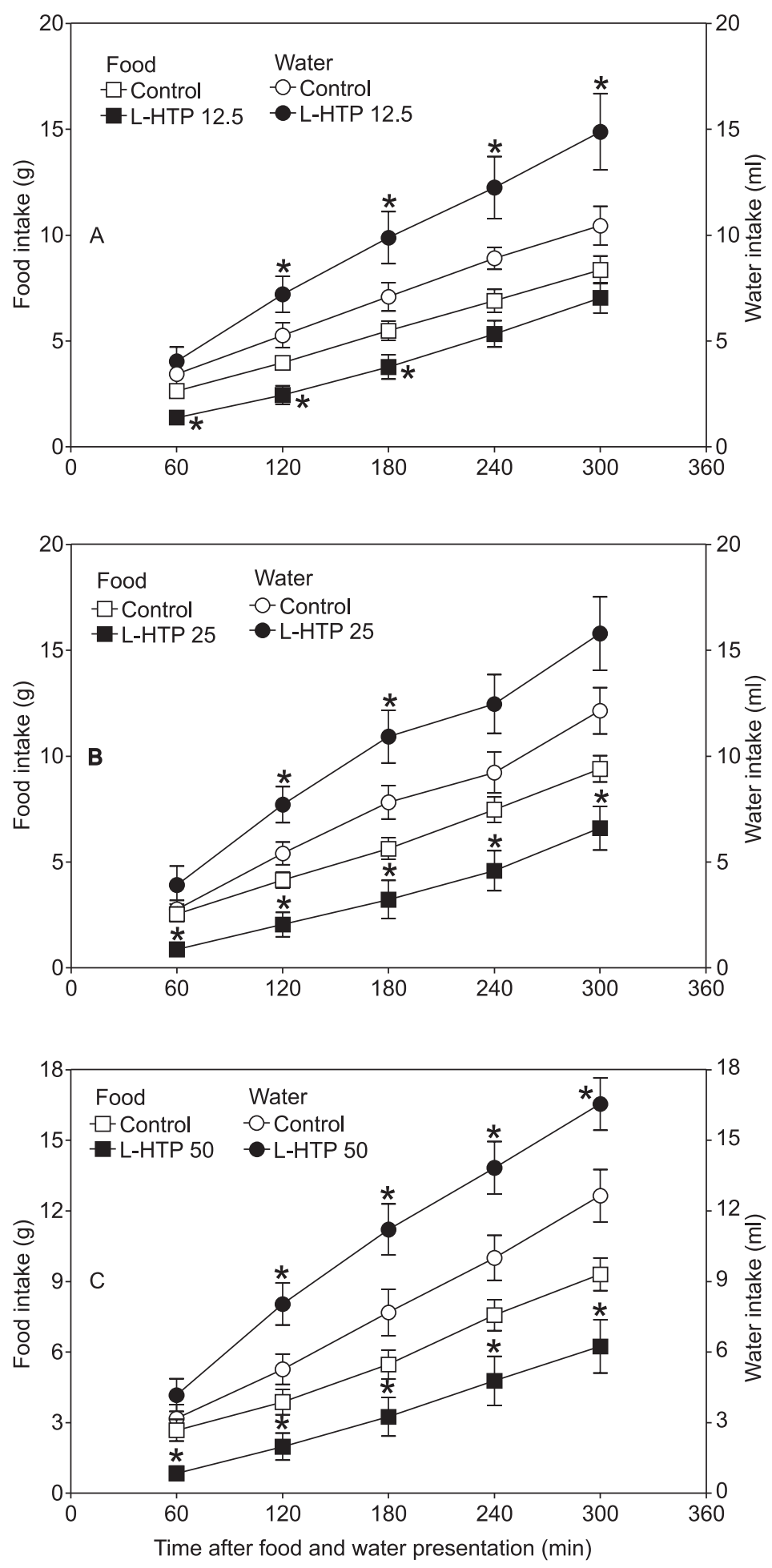

Fig. 4 - Effect of treatment with L-5-hydroxytryptophan (L-HTP), 12.5 (A), 25.0 (B), and 50.0 (C) mg/kg, ic, 1 min before food and water presentation, on food and water intake in quails (Coturnix japonica) submitted to a $6 \mathrm{~h}$ fast. Data are reported as means \pm SE. *p $<0.05$ compared to the control group. 

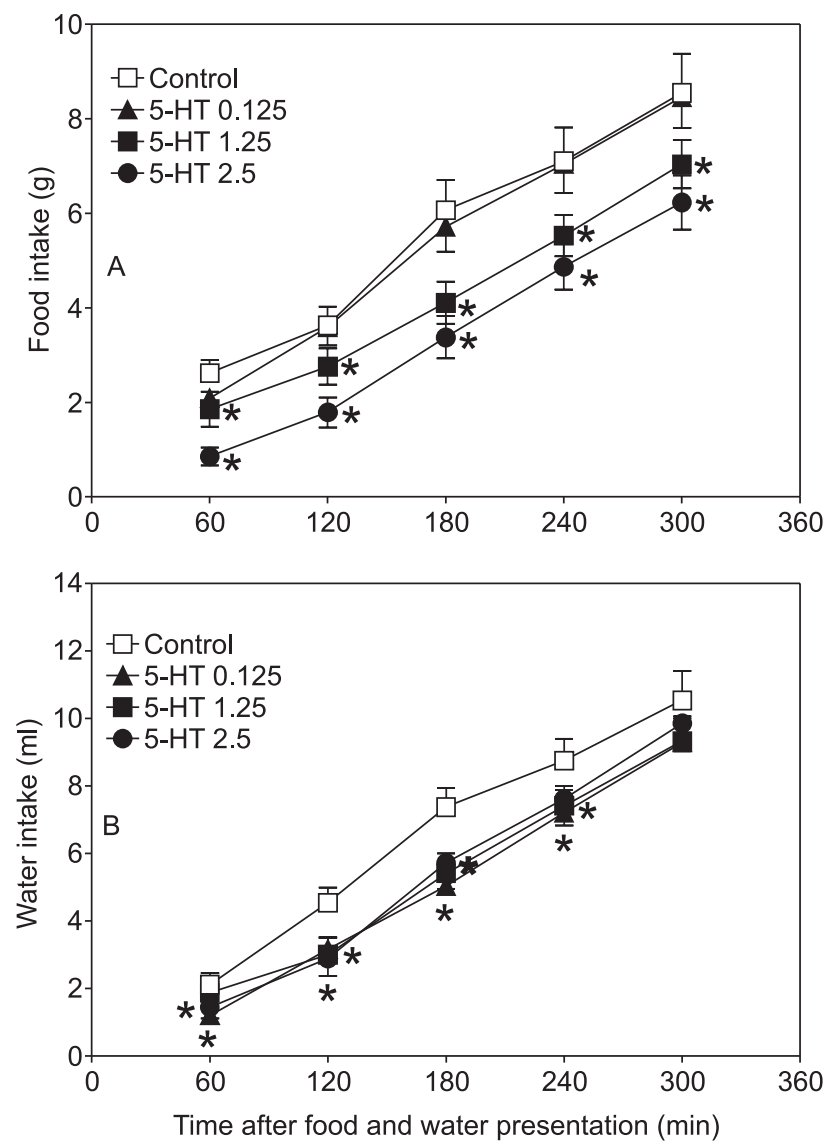

Fig. 5 - Effect of treatment with serotonin (5-HT) at doses of $0.125,1.25$, and $2.5 \mathrm{mg} / \mathrm{kg}, s c, 1 \mathrm{~min}$ before food and water presentation, on the food (A) and water (B) intake in quails (Coturnix japonica) submitted to a $6 \mathrm{~h}$ fast. Data are reported as means $\pm \mathrm{SE}$. $* \mathrm{p}<$ 0.05 compared to the control group.

The stress generated by fasting in a granivorous bird is a factor that should be taken into consideration within this context (Carsia \& Harvey, 2000). Other mammalian models of stress have shown an increase in neuronal uptake of serotonin precursors (Joseph \& Kenneth, 1983; Shimizu et al., 1992). Under the conditions in which the present experiment was carried out, the stress generated by fasting possibly anticipated peak serotonin production, thus abolishing its effect on food intake response after $60 \mathrm{~min}$.

The hypophagic response induced by serotonin administration was probably due to the central action of this amine, although a peripheral effect cannot be ruled out. Serotonin-injected birds developed a hypnogenic response over a period of more than 10 min. In this first report demonstrating the hypnogenic effect of serotonin after peripheral administration in birds, what is implied is that, in contrast to mammals, this amine crosses the blood-brain barrier in quails (Cooper et al., 1996). It may also be suggested that the hypnogenic effect influences at least partially, the hypophagic response developed. In addition, L-HTP also provoked hypnogenic action as well as a reduction in food intake; however, in contrast to responses in birds treated with serotonin, the precursor increased water intake (see below). Although the hypnogenic effect of L-HTP was less intense, we assume that the decline in the alert state did not influence drastically the activation of the motor components implicated in the ingestive response. Concomitant development of a potent dipsogenic response was observed at least 5 to 30 min after injection, which obviously required the action of the motor circuits underlying water intake.

Recent evidence indicates that the dipsogenic response elicited by L-HTP may depend on the 
release of a peripheral dipsogen (unpublished data), as has been suggested for mammals (Fregly et al., 1980). Studies are underway in our laboratory to determine the role of the renin-angiotensin system in the dipsogenic response induced by L-HTP.

In contrast to rats (Kikta et al., 1981, 1983), water intake was inhibited in quails after serotonin administration. Although part of this inhibitory action seems to be related to the state of somnolence, we favor the hypothesis that another inhibitory component is implicated in the hypodipsic response to serotonin.

In mammals, the hyperdipsic response reported for L-HTP has been seen as requiring, at least in part, the peripheral conversion of this precursor into serotonin (Kikta et al., 1981). This conclusion was not confirmed by our studies.

The present results suggest the involvement of serotonergic pathways in the control of food intake in quails. They also show, for the first time, hypnogenic action induced by serotonin and a hyperdipsic effect mediated by L-HTP.

Acknowledgements - The authors thank FAPERJ for supporting the line of research on the neurobiology of feeding behavior in birds carried on at the Department of Physiological Sciences, UFRuralRJ.

\section{REFERENCES}

AZMITIA, E. C. \& SEGAL, M., 1978, An autoradiographic analysis of the differential ascending projections of the dorsal and median raphe nuclei in the rat. J. Comp. Neurol., 179: 641-668.

AZMITIA, E. C., 1987, The CNS serotonergic system: progression toward a collaborative organization. In: H. Y. Meltzer (ed.), Psychopharmacology: third generation of progress. Raven Press, New York, pp. 61-73.

BLUNDELL, J. E. \& HILL, A. J., 1987, Nutrition, serotonin and appetite: case study in the evolution of a scientific idea. Appetite, 8: 183-194.

BLUNDELL, J. E., 1984, Serotonin and appetite. Neuropharmacology, 23: 1537-1551.

BLUNDELL, J. E., 1991, Pharmacological approaches to appetite suppression. TIPS, 12: 147-157.

BOADLE-BIBER, M. C., 1993, Regulation of serotonin synthesis. Prog. Bioph. Mol. Biol., 60(1): 1-15.

CARSIA, R. V. \& HARVEY, S., 2000, Adrenals. In: G. C. Whittow (ed.), Sturkie's Avian Physiology, 5th ed. Academic Press, San Diego, pp. 489-537.

CHALlET, E., MICELI, D., PIERRE, J., REPERANT, J., MASICOTTE, G., HERBIN, M. \& VESSELKIN, N. P. 1996, Distribution of serotonin-immunoreactivity in the brain of the pigeon (Columba livia). Anat. Embryol., 193(3): 209-227.

COZZI B., VIGLIETTI-PANZICA C., ASTE N. \& PANZICA G. C., 1991, The serotoninergic system in the brain of the Japanese quail. An immunohistochemical study. Cell Tissue Res., 263(2): 271-284.
CURZON, G., 1990, Serotonin and appetite. In: Neuropharmacology of serotonin. Ann. N. Y. Acad. Sci., 600: 521-531.

CURZON, G., 1991, Effects of tryptophan and of 5hydroxytryptamine receptor subtype agonists on feeding. $A d v$. Exp. Med. Biol., 294: 377-388.

DUBE, L. \& PARENT, A., 1981, The monoamine-containing neurons in avaian brain: I. A study of acetylchonesterase histochemistry. J. Comp. Neurol., 196: 695-708.

DUCHALA, C. S., OTTINGER, M. A. \& RUSSEK, E., 1984, The developmental distribution of monoamines in the brain of male Japanese quail (Coturnix coturnix japonica). Poult. Sci., 63(5): 1052-1060.

FERNSTROM, J. D. \& WURTMAN, R. J., 1971a, Brain serotonin, content: increase following ingestion of carbohydrate diet. Science, 174: 1023-1025.

FERNSTROM, J. D. \& WURTMAN, R. J., 1971b, Brain serotonin content: physiological dependence on plasma tryptophan levels. Science, 73: 149-152.

FERNSTROM, J. D., 1983, Role of precursor availability in control of monoamine biosynthesis in brain. Physiol. Rev., 63: 484546.

FREGLY, M. J., CONNOR, T. M., KIKTA, D. C. \& THREATTE, R. M., 1980, Dipsogenic effect of L-5-hydroxytryptophan in rats. Brain Res. Bull., 5: 719-724.

JOSEPH, M. H. \& KENNETH, G. A., 1983, Stressed-induced release of 5-HT in the hippocampus and its dependence on increased tryptophan availability: an in vivo electrochemical study. Brain Res., 270: 251-257.

KIKTA, D. C., THREATTE, R. M., BARNEY, C. C., FREGLY, M. J. \& GREENLEAF, J. E., 1981, Peripheral conversion of L-5-hydroxytryptophan to serotonin induces drinking in rats. Pharmacol. Biochem. Behav., 14: 889-893.

KIKTA, D. C., BARNEY, C. C., THREATTE, R. M., FREGLY, M. J., ROWLAND, N. E. \& GREENLEAF, J. E., 1983, On the mechanism of serotonin-induced dipsogenesis in the rat. Pharmacol. Biochem. Behav., 19: 519-525.

PARENT, A., 1981. Comparative anatomy of serotoninergic systems. J. Physiol., 77: 147-156.

PARENT, A., DESCARRIES, L. \& BEAUDET, A., 1981, Organization of ascending serotonin systems in the adult rat brain. A radioautographic study after intraventricular administration of $\left[{ }^{3} \mathrm{H}\right] 5$-hydroxytryptamine. Neuroscience, 6: 115-138.

ROSEBROUGH, R. W., 1996, Crude protein and supplemental dietary tryptophan effects on growth and tissue neurotransmitter levels in the broiler chicken. Br. J. Nut., 76: 87-96.

SAKO, H., KOJIMA, T. \& OKADO, N., 1986, Immunohistochemical study on the development of serotoninergic neurons in the chick: I. Distribution of cell bodies and fibers in the brain. J. Comp. Neurol., 253: 61-78.

SHIMIZU, N., TAKE, S., HORI, T. \& OOMURA, Y., 1992, In vivo measurement of hypothalamic serotonin release by intracerebral microdialysis: significant enhancement by immobilization stress in rats. Brain Res. Bull., 28: 727-734.

TYCE, G. M., 1990, Origin and metabolism of serotonin. $J$. Cardiovasc. Pharmacol., 16: S1-S7.

THOMAZ, C. M., ALMEIDA, A. C., OLIVARES, E. L., BADAUÊ-PASSOS Jr., D., MARINHO Jr., A. \& REIS, L. C., 1998, Influência do tratamento com precursores da serotonina no comportamento ingestivo de codornas (Coturnix japonica). In: Resumos da XIII Reunião Anual da FeSBE, Caxambu, MG, p. 53. 